\title{
The Corporate University Landscape in Indonesia
}

\author{
Hani Gita Ayuningtias \\ School of Economic \& Business, Telkom University \\ 40267 Bandung, Indonesia \\ hanigita@gmail.com
}

\author{
Annisa Nurbaiti \\ School of Economic \& Business, Telkom University \\ 40267 Bandung, Indonesia \\ annisa.nurbaiti@yahoo.com
}

\author{
Grisna Anggadwita \\ School of Economic \& Business, Telkom University \\ 40267 Bandung, Indonesia \\ grisnamailbox@yahoo.co.id \\ Mediany Kriseka Putri \\ School of Economic \& Business, Telkom University \\ 40267 Bandung, Indonesia \\ mediany.kris@gmail.com
}

\begin{abstract}
Corporate university phenomenon is not new; General Motors began the GM institute in 1927. After that corporate university grew quickly until 1900s when the number of corporate universities increased to 1800 . Today, it is reported that there are 2400 corporate universities. Some $\mathbf{4 0 \%}$ of Fortune 500 companies already have a corporate university. Corporate University is a name given to the virtual engine that acts as an umbrella, bringing together all the existing training and development units within the corporation to ensure the effective and efficient deployment of all organizational learning initiatives as a strategic and operational enabler. Corporate University should link learning to organization performance. This paper presents an overview landscape of corporate university in Indonesia. Several multinational companies such as PT Telkom Indonesia, PT Pertamina, and PT PLN have implemented corporate university, share their experience in setting up the Corporate University, and how corporate university helps to energize the organization performance. The purpose of this study is to try to explain the contribution and understand the concept of corporate university and to describe the reasons that it is important for corporate university to develop in Indonesia. This paper develops the conceptual model by summarizing existing theories and comparing the different models of corporate university in several multinational companies.
\end{abstract}

Keywords-Conceptual Model, Corporate University, Multinational Company, Organizational Learning, Organizational Performance.

\section{INTRODUCTION}

In human resources literature, new trend in human resources training and development describes the corporate university [1]. According to the official statistics in USA more than 1,800 corporate universities are now in existence; 40 percent of the fortune 500 companies have implemented a corporate university [2]

In Indonesia the label ñcorporate universityò first appeared in 2012. The first corporate university in Indonesia is Telkom Corporate University, [3] but Pertamina is the first company in Indonesia to rank 122 on Fortune. [3] Pertamina implemented Pertamina Learning Center (PLC) before its transformation into corporate university.
Corporate universities are growing for a number of reasons. Some businesses want to systemize training functions or maximize the investment in education. Other corporations want to develop the employment of workforce and remain competitive in the market place [4].

Corporate universities typically are established to provide education at a lower cost, relative to programs offered by traditional universities [5]

\section{LITERATURE REVIEW}

Currently, the role and development of the Corporate University (CU) received increased attention both from academia, government, and corporate. CU concept has been developed in Europe and become a significant aspect as a center for training and development of human resources [6]. Not only in Europe, in some countries for example Indonesia, CU becomes an important aspect for the company to make a real contribution of human resources development through education. According to Eccles [3], the development of CU represents a paradigm shift in the strategic development of human resources, or, a repackaging of the training function.

The main concept of $\mathrm{CU}$ is based on the literature review: 1. Functional approach focuses on the $\mathrm{CU}$ training issues; $\mathrm{CU}$ has evolved in many organizations to become a strategic umbrella to educate not only the employees but also stakeholders who play a role in the development of the organization such as customers and suppliers. Key elements drawn from this approach is to focus on the basic skills and the need to develop a consistent and uniform knowledge, skills and abilities throughout the organization, and a network of customers and suppliers, to ensure consistent quality of the products and/or services. 2 . The strategic approach associated with long-term development of the human resources organization. According to [6], the definition of CU is the idea of a corporate university for learning and knowledge creation of formal and processes within an organization. The definition emphasizes the strategic focus on knowledge creation and management across the organization. Some of the elements that make up the two major concepts are focused on training and development; and, investing continuously to improve the human capital of the organization. This is consistent with the theory of human capital, which connects investments as key 
assets of the organization, employees, improved productivity, and sustainable competitive advantage [1]; [7]; [8].

Strategic approach emphasizes the enhancement of corporate resources by linking skills development with the retention of employees through incentives such as career advancement, improved security and higher remuneration. This is also consistent with the resource-based view, in which organizations maintain and develop these resources in a way that they become rare, valuable and difficult to imitate, and further enhance the organization's competitive advantage [9].

This strategy focused on the management and development of human resources can be associated with the promotion of $\mathrm{CU}$ as a catalyst for the strategic development of human resources. Organizations take a strategic step for the long term and a different approach to managing and investing in human resources, to ensure that appropriate trainings and development are available to all employees. A common approach for underlying $\mathrm{CU}$ is the use of strategic management development center to build skills and exchange of information [10].

Learning and knowledge management within the organization in an environment that is more complex and competitive reflect the strategic role of $\mathrm{CU}$ in the creation of competitive advantage [2]; [5]; [6]. In a dynamic environment, CU strategy must develop diverse and adaptive approaches, to ensure that every element in the organization has accesses to appropriate trainings and developments to meet the diverse organizational goals.[11] There are four main processes identified as a core element of corporate universities: systems and process of knowledge; networking and process of partnership; learning process; and, people process.

A conceptual framework is established for developing corporate universities in the context of Chinese organizations [4]. The process model proposed by [11] fails to distinguish the uniqueness of each university corporation and does not handle the peculiarities of corporate universities. A combination of all of the functional components of corporate universities was found by [12]. A review on the literature shows that the majority of university research on the company is performed in the context of the West, and how the corporate university models is applied in developing countries is still unknown. Their framework on the idea is that a corporate university should not only be aligned with knowledge management and organizational learning but it is also important in social practices, technologies and organizations that support learning and knowledge creating organizational processes [11].

The development of the university enterprise using a central management issues can be traced to 1990 , such as the learning organization, core competence, knowledge management, network management and organizational learning as a core element of the strategic process [13]. The concept of a corporate university is a relatively new phenomenon, the product of the last quarter of the twentieth century. As a result, the debate about what it is, what it does, and how it operates is still emerging.

\section{ReSEARCH Methodology}

Research design that has been used in this study is exploratory method as an effort to reveal various factors that influence the lanscape of corporate university in Indonesia. The research method that has been used in this study is descriptive approach by building relationship between two or more variabels.

This study started from literature review by defining the concept of corporate university at multinational companies in Indonesia such as PT Telkom Indonesia, PT Pertamina, and PT PLN. This paper builds a conceptual model to explain contribution in understanding the concept of corporate university and to describe the reasons why corporate university is important to be developed in Indonesia.

\section{DATA ANALYSIS AND Discusion}

\subsection{Corporate University in Indonesia}

Based on [14] CU is ña function strategically aligned toward integrating the development of people within specific organization and must focus on personal development, career paths, training opportunities, learning events, human resource programs, and leadership at all level of the organizationò.

The company uses the $\mathrm{CU}$ as a vehicle to create, distribute, and manage the knowledge. On the other hand, the phenomenon of CU is an essential tool to help human resource units in managing the talent strategically. CU offers development opportunities focusing on strategy, reflecting the company's priorities and anticipating changes.

$\mathrm{CU}$ as a global learning solution is established in fast-food giant company, such as McDonald's Corporation which established the Hamburger University in the suburbs of Chicago in 1961. Motorola University (MU) provides a wide range of business courses based on Six Sigma business philosophy created by Motorola which spreads across the US, UK, and Canada. Billionaire Donald Trump Sr and Trump established the Trump University that provides a variety of services in entrepreneurship, real estate, business management, and investment all over US.

Those three companies above have been going on for decades. In Indonesia, major companies were recently created CU around 2012.

Among the three multinational companies in Indonesia (PT. Telkom Indonesia, PT. Pertamina, PT. PLN), CU is a long-term investment under the HRD unit and gets full support from the management.

There are several reasons why general learning center is transformed into a corporate university [15]. The executives apparently become increasingly aware that the form of training, training center, or the learning center have some common shortcomings, namely:

First, the absence of alignment between what is learned in training and what is needed by business in companies. Common learning in training, training center, or learning center is apart from the most pressing business problems to be solved. 
Second, training programs and development often do not have significant business impact since they are not directly aligned with corporate business issues; the impact of the training results towards business performance is insignificant.

Third, generally the participation of trainees is very low. One possible cause is because generally the participants feel that they do not get meaningful appreciation after attending the training. For example, achievement in training does not increase their salary or their career path even if the employee joined the training, possibly with no full commitment.

In this case, $\mathrm{CU}$ is more superior compared to trainings and development in ensuring the knowledge, skills and attitude that can be applied in the company. It also has a strong linkage and significant impact towards the company's business performance.

Because of those reasons, PT. Telkom Indonesia, PT. Pertamina, PT. PLN and and other companies are encouaged to transform their training center or their learning center become Corporate University.

$\mathrm{CU}$ assessment criteria include seven main aspects, namely: Alignment, Alliances, Branding, Launching, Leadership, Learning Technology, and Measurement. Alignment assessment is the extent to which the effort of learning and development is aligned with corporate objectives. Alliance measures how qualified the use of external service providers are. Branding measures the success of the development and implementation of communication strategies and innovative brand development. Launching is an initiative to measure the success of the launch of new CUs. Leadership is measured by the implementation of major impacts of leadership programs for managers, high-potential employees, and senior executives. Learning Technology is measured by the extent to which CU can create learning environments by using technology. Measurement assesses the ability of CU in creating tools and techniques for measuring investment in learning. In every aspect of assessment, there are three subcategories: Excellence, Best Practice, and Exemplary Practice [16].

CU must go through a number of stages to achieve this strategic level [17] (Figure 1):

\begin{tabular}{|l|l|l|lr|}
\hline Features & $\begin{array}{l}\text { Operational } \\
\text { Phase }\end{array}$ & Tactical Phase & Strategic Phase \\
\hline Type of CU & $\begin{array}{l}\text { ñAdvanced } \\
\text { training } \\
\text { departmentò }\end{array}$ & $\begin{array}{l}\text { ñKnowledge back- } \\
\text { boneò }\end{array}$ & $\begin{array}{l}\text { ñKnowledge } \\
\text { factoryò }\end{array}$ & and \\
\hline Goal & Efficiency & $\begin{array}{l}\text { In line with } \\
\text { organizational } \\
\text { goals }\end{array}$ & $\begin{array}{l}\text { Surpass } \\
\text { competition }\end{array}$ & and \\
\hline $\begin{array}{l}\text { Relation } \\
\text { with strategy }\end{array}$ & $\begin{array}{l}\text { Indirect and reactive } \\
\text { reactive }\end{array}$ & $\begin{array}{l}\text { Direct } \\
\text { proactive }\end{array}$ \\
\hline $\begin{array}{l}\text { Main } \\
\text { activity }\end{array}$ & $\begin{array}{l}\text { training } \\
\text { activities within } \\
\text { the company }\end{array}$ & $\begin{array}{l}\text { Building courses } \\
\text { based on } \\
\text { organizational on } \\
\text { strategy }\end{array}$ & $\begin{array}{l}\text { Development of } \\
\text { strategy } \\
\text { training } \\
\text { research }\end{array}$ \\
\hline
\end{tabular}

Fig. 1. Phases of Corporate University (CUs)

Discussing about the company in Indonesia, PT. Telkom has Telkom Corporate University which was established on September 28, 2012 at Bandung Gegerkalong area. Telkom
$\mathrm{CU}$ is certified according to international standards in order to achieve the goal of an international company. Telkom CU embodies the investment in People and supports the achievement of the company's business performance. Telkom Group cooperates fully with HRD in the planning, management, and development to ensure the success of the mission. Telkom CU has advantages in having strong investments in management, global talent program, and good accountability from all stakeholders. All of those things underlie the creation of CU. Telkom CU has 11 Deans whose members are all Telkom Business Director \& CEO of Telkom Group's flagship subsidiary, while the Rector is concurrently the chairman of the learning committee of Telkom CU, i.e. Director of Telkom

The second is the state-owned company PT. Pertamina, which has PCU (Pertamina Corporate University) established on December 7, 2012 Simprung Jakarta region. Before the establishment of the PCU, PT. Pertamina experienced three phases, namely:

1. Build the Core Phase (2012-2013),

2. Adjacent launch phase (2014-2015),

3. Phase-out step along the value chain (2016-2020).

PCU is the first world-class oil and gas fields facility in Indonesia which has created a benchmark for the industry in Indonesia. PCU received full support from the management to the sustainability of this CU.

The third company is PT. PLN. PT. PLN has PLN CU which was established in November 2012. Until now, only employees of PT. PLN participated in the PLN CU, but for the future management of the public, it will allow the partners of the company as its participants. Commencing a new age of PLN CU, it is still present, and it has been successful in the field of trademark, software and harware or infrastructure.

If explored, the three companies have the same background in creating corporate univesities. They start from the problems encountered in the delivery of training, the goal to be achieved from each of the training, the training strategy that can create the achievement of corporate goals, method learning given to the employees, and the development of soft skills. This underlying CorpU formation can be illustrated in Figure 2:

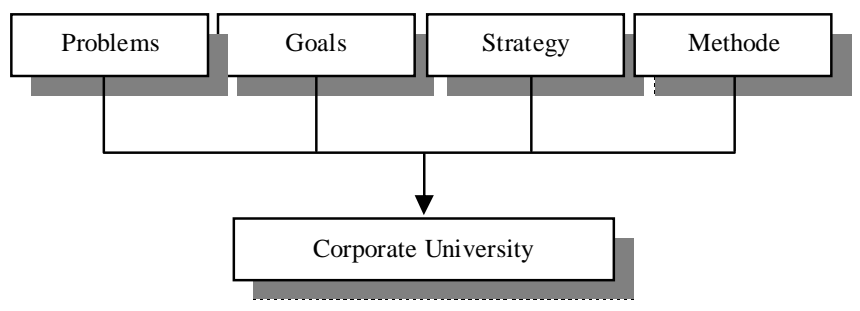

Fig. 2. Corporate University Strategy 


\subsection{Conceptual Model}

Corporate University priority is to increase the intelligence of the company to make changes, execute strategic initiatives, and spread "best practices" between the business units and from outside.

Figure 3 below is a conceptual model proposed in this study. Establishment of $\mathrm{CU}$ is essential to achieve the objectives of the corporate strategy, where a business process (product development, operations, sales and marketing, and human resource development) made by the company is supported by adequate competence and skills of human resources.

$\mathrm{CU}$ is one of the company's main programs to produce qualified employees as needed, where one of the $\mathrm{CU}$ functions is also as a center of competence and skill enhancement of employees. Learning strategy and focus aim to improve the quality of employees as well as part of the talent management/leadership development program, through which a learning program provided can be a means to achieve the career management of employees according to the needs of the company. To produce qualified talent management, the focus of the corporate university is to provide adequate learning and academic infrastructure system tailored to the needs of the company. Of course, the existence of the CU should be able to follow the dynamic of the environment, both the needs of the market and the competitiveness of the competitors.

Learning infrastructure provided by corporate learning should facilitate all means necessary, including the governance and structure of the CU itself. CU should also facilitate the process of partership and alliances in order to share knowledge with the various stakeholders (government, industry, academician, and community), collaboration and synergies of the various parties that can enhance the learning process that occurs. Another infrastructure is the availability of assessment centers and learning and research center as a forum for participants to facilitate their CU in broadening and deepening knowledge, measuring and evaluating the extent of their knowledge.

Academic curriculum structure system is established for the process of learning; the goal resulting from academic system is to facilitate the employees to achieve the company's goals. Some academic systems that can be done are learning and assessment; learning levels consist of foundation, competency, and mastery, and the core content and research. In the process of academic systems, $\mathrm{CU}$ are expected to involve Academician practitioners and experts in the field, in order to create integration between academic and practice. Thus, CU participants do not only understand from the practical side, but also know contemporary theories related to the field they pursue.

Establishment of CU cannot just rely on the trend bandwagon only because it requires a large cost for consideration of the company itself.

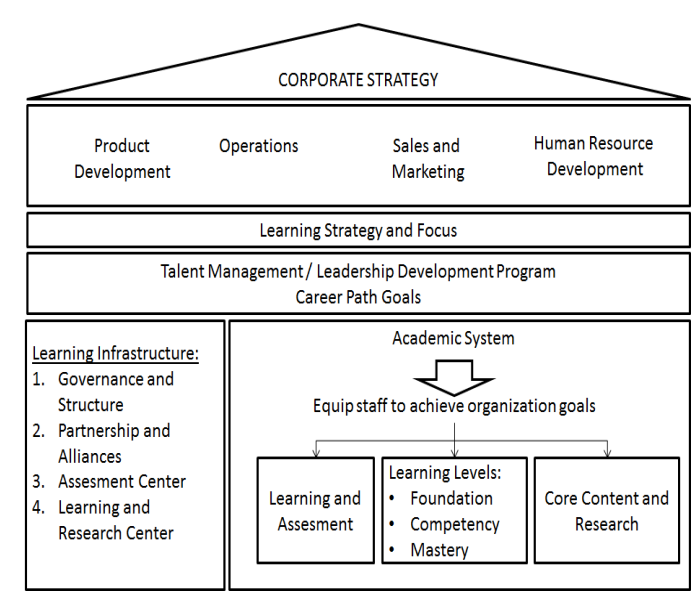

Fig. 3. Conceptual Model

\section{CONClusion}

Corporate University is designed to give the employees so many business knowledge, managerial competence, and education which are oriented at work, directed to a competitive organization.

In Indonesia, CU system is very needed for big companies to improve the quality of human resouce to be fully competent in knowledge and skill so that they can compete internationally and contribute fully to the companyôs performance.

\section{References}

[1] M. Andersen, òThe corporate university lanscape in Germanò.Journal Workplace Learning, Vol. 19 No.2, 2007, pp.109-123.

[2] AACSB.òCorporate universities emerge as pioneers in market-driven education-1999 survey of corporate university future directionò. AACSB Newsline, Spring. 1999.

[3] Cover Story., ñCorporate University : Berinvestasi Ladang Emasò Human Capital Journal No. 25 Tahun III, 2013.

[4] S. Dillich, òCorporate universitiesò, Computing Canada, 4 August, Vol.26 No.16, 2000, pp.25-31.

[5] J. Nixon, òCorporate universities vs higer education institutionsòJournal insutrial and commercial training, Vol.34, No.4, 2002, pp.144-150.

[6] A. Smith, Training and Development in Australia, 2nd ed., Sydney, New South Wales: Butterworth, 1998

[7] G. Eccles, ñMarketing the CU or Enterprise Academyò, Journal of Workplace Learning, Vol. 16 No. 7, 2004, pp. 410-17.

[8] F. Jansink, ñThe knowledge-productive corporate universityò. Journal of European Industrial Learning. 29(1), 2005, pp. 40-57.

[9] M. Andresen, A.H. Cascorbi, and M. Harms, ñCorporate universities Ï a systematisation of the concept and explanation of their role in a global environment,ò in Morley, M.J., Cross, P.C., Flood, C., Gubbins, C. and Heraty, N. (Eds), Exploring the Mosaic, Developing the Discipline, Full Proceedings of the 7 th Conference on IHRM, University of Limerick, Ireland, 4-6 June, 2003.

[10] J. Li, and M. Alagaraja, ñEmergence of corporate universities,ò paper presented at the Fifth Academy of Human Resource Development Asian Research Conference. Kuala Lumpur, December, 2006.

[11] T. Schultz, ñInvestment in man: an economistôs view,ò The Social Service Review., Vol. 33, No. 2, 1959, pp. 109-17. 
[12] S. Taylor, and R. Paton, ñCorporate Universities $\ddot{i}$ Historical Development, Conceptual Analysis and Relations with Public-Sector Higher Education,ò The Observatory on Borderless Higher Education, London, 2002.

[13] G.S. Becker, Human Capital: A Theoretical Analysis with Special Reference to Education, New York: Colombia University Press, 1964

[14] J.W. Grenzer, Developing and Implementing a Corporate Amherst: University.HRD Press Inc., 2006.

[15] D. Thomas, ñSeminar on corporate business schools, ò Henley Management College, Henley, 28 October 1999.

[16] J. Barney, ñFirm resources and sustained competitive advantageò, Journal of Management, Vol. 17 No. 1, 1991, pp. 99-120.

[17] R. Deiser, ñCorporate universities ï Modeerscheinung oder strategischer Erfolgsfaktor?ò, Organisation sentwicklung, Vol. 17 No. 1, 1998, pp. $36-49$. 